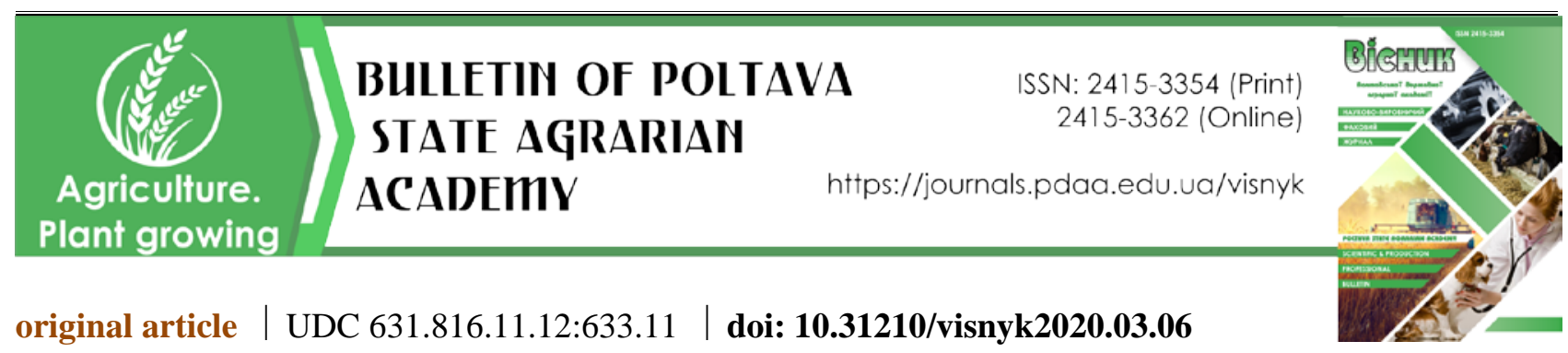

\title{
THE INFLUENCE OF MINERAL FERTILIZERS ON WATER CONSUMPTION AND PRODUCTIVITY OF WINTER WHEAT
}
V. V. Hanhur ${ }^{1 *}$
A. A. Kocherha ${ }^{1}$
O. S. Pypko ${ }^{1}$
Y. I. Kabak ${ }^{1}$
O. I. Len $^{2}$

\author{
ORCID (iD) 0000-0002-5619-492X \\ ORCID (1D 0000-0002-2076-4230
}

${ }^{1}$ Poltava State Agrarian Academy, 1/3, Skovorody str., Poltava, 36000, Ukraine

${ }^{2}$ Poltava State Agricultural Experimental Station named after M. I. Vavylov of the Institute of Pig Breeding and Agro-Industrial Production of the National Academy of Agrarian Sciences of Ukraine, 86, Shvedska str., Poltava, 36014, Ukraine

*Corresponding author

E-mail: volodimirgangur@gmail.com

How to Cite

Hanhur, V. V., Kocherha, A. A., Pypko, O. S., Kabak, Y. I., \& Len, O. I. (2020). The influence of mineral fertilizers on water consumption and productivity of winter wheat. Bulletin of Poltava State Agrarian Academy, (3), 54-60. doi: 10.31210/visnyk2020.03.06

The priority task of the agro-industrial complex of Ukraine is increasing the manufacturing of grain products with improved quality indicators for ensuring food security of the state and exports to foreign markets. The decisive role in solving this problem belongs to winter wheat (Triticum aestivum L.), as a leading food grain crop. The aim of the research was to determine the effect of different rates of mineral fertilizers, differentiated application of nitrogen on water consumption of winter wheat plantings and the level of grain productivity. During the research the following scientific methods were used: analysis, synthesis, field, and statistical. The results of the conducted studies show that different doses of mineral fertilizers and differentiated nitrogen application, as a significant factor influencing the activity of growth processes, led to an increase in tillering rate by $14.6-34.7 \%$, plant height $2.9-8.7 \%$, the number of grains in the spike by $1.8-$ $10.1 \%$, as compared with the variant without fertilization. It has been found that mineral fertilizers increase the effectiveness of using available soil moisture for the formation of winter wheat yield, in particular, total water consumption made $539-579 \mathrm{~m}^{3} / \mathrm{t}$, which was $46-86 \mathrm{~m}^{3} / \mathrm{t}$ or $7.4-13.8 \%$ less than in the control. The tendency was registered for more rational using moisture to form a yield unit of the main product in case of transferring part of nitrogen from basic application to early spring fertilization. It has been found that due to applying mineral fertilizers in the technology of winter wheat cultivation, a significant increase in grain yield is achieved in comparison with the variant without fertilizers. The value of additional wheat grain yield on experimental plots was $0.45-0.92 \mathrm{t} / \mathrm{ha}$ or $8.8-17.7 \%$ relative to the control. The best conditions of mineral fertilization, which ensured the maximum winter wheat yield of $6.11 \mathrm{t} / \mathrm{ha}$ were registered under applying fertilizers at the rate of $N_{80} P_{90} K_{50}+N_{30}$. A steady tendency to increasing winter wheat productivity under applying fertilizers' mineral nitrogen in different periods was observed.

Key words: soft winter wheat (Triticum aestivum L.), mineral fertilization, crop protection, water consumption, available moisture, yield. 


\title{
СІЛЬСЬКЕ ГОСПОДАРСТВО. РОСЛИННИЦТВО
}

\section{ВПЛИВ МІНЕРАЛЬНИХ ДОБРИВ НА ВОДОСПОЖИВАННЯ ТА ПРОДУКТИВНІСТЬ ПШЕНИЦІ ОЗИМОї}

\author{
В. В. Гангур ${ }^{1}$, А. А. Кочерга ${ }^{1}$, О. С. Пипко ${ }^{1}$ Ю. І. Кабак ${ }^{1}$, О. І. Лень ${ }^{2}$ \\ ${ }^{1}$ Полтавська державна аграрна академія, м. Полтава, Україна \\ ${ }^{2}$ Полтавська державна сільськогосподарська дослідна станція імені М. І. Вавилова Інституту свинар- \\ ства і АПВ НААН, м. Полтава, Україна
}

Визначальна роль у збільшенні обсягів виробництва продовольчого зерна належить пшениці озимій (Triticum aestivum L.). Метою досліджень було з'ясувати вплив різних норм мінеральних добрив, диференційованого застосування азоту на водоспожсивання посівів пшениці озимої та рівень зернової продуктивності. Під час проведення досліджень використано такі наукові методи: аналіз, синтез, польовий, статистичний. Результати досліджень свідчать, щяо різні дози мінеральних добрив та диференційоване використання азоту як вагомих чинників упливу на активність ростових процесів зумовили зростання коефіцієнта кущіння на 14,6-34,7 \%, висоти рослин 2,9-8,7 \%, кількості зернин у колосі на 1,8-10,1\% порівняно з варіантом без внесення добрив. Встановлено, що мінеральні добрива підвищують ефективність використання доступної вологи трунту на формування врожаю пшениці озимої, зокрема сумарне водоспоживання становило 539-579 $\mathrm{m}^{3} / \mathrm{m}$, що на 46-86 $\mathrm{m}^{3} / \mathrm{m}$ або 7,4-13,8\% менше, ніж у контролі. Відзначено тенденцію щэодо більш раціонального використання вологи на утворення одинииі врожаю основної продукції за умови перенесення частини азоту із основного внесення в ранньовесняне підживлення. Виявлено, щз за рахунок використання мінеральних добрив у технології вирошування пшенищі озимої досягається істотне підвищення урожайності зерна культури порівняно з варіантом без добрив. Величина додаткового врожаю зерна пшениці на експериментальних ділянках по відношенню до контролю становила 0,45-0,92 m/2а або 8,8-17,7 \%. Найкращі умови мінерального живлення, які забезпечили максимальну урожсайність пшеничі озимої $6,11 \mathrm{~m} / 2 a$, формувалися за умови внесення добрив у нормі $N_{80} P_{90} K_{50}+N_{30}$. Відзначено стійку тенденцію щзоо підвищення продуктивності посівів пшеничі озимої за умови різночасного використання мінерального азоту добрив.

Ключові слова: пшениця м'яка озима (Triticum aеstivum L.), мінеральне живлення, захист посівів, водоспоживання, доступна волога, урожсайність.

\section{ВЛИЯНИЕ МИНЕРАЛЬНЫХ УДОБРЕНИЙ НА ВОДОПОТРЕБЛЕНИЕ И ПРОДУКТИВНОСТЬ ОЗИМОЙ ПШЕНИЦЫ}

\author{
В. В. Гангур ${ }^{1}$, А. А. Кочерга ${ }^{1}$, А. С. Пипко ${ }^{1}$ Ю. И. Кабак ${ }^{1}$, А. И. Лень ${ }^{2}$ \\ ${ }^{1}$ Полтавская государственная аграрная академия, г. Полтава, Украина \\ ${ }^{2}$ Полтавская государственная сельскохозяйственная опытная станция имени Н. И. Вавилова Инсти- \\ тута свиноводства и АПП НААН, г. Полтава, Украина
}

Результаты исследований Полтавской государственной сельскохозяйственной опытной станции имени Н. И. Вавилова свидетельствуют, что минеральные удобрения повышают эффективность использования доступной влаги почвы на формирование урожая озимой пшеницы, в частности суммарное водопотребление составило 539-579 $\mathrm{m}^{3} / \mathrm{m}$, что на 46-86 $\mathrm{m}^{3} / \mathrm{m}$ или 7,4-13,8 \% меньше, чем на контроле. Лучшие условия минерального питания, которые обеспечили максимальную урожайность озимой пшениць 6,11 m/2а, формировались при внесении удобрений в норме $N_{80} P_{90} K_{50}+N_{30}$.

Ключевье слова: пиеница мягкая озимая (Triticum aestivum L.), минеральное питание, защита посевов, водопотребление, доступная влага, урожайность.

\section{Вступ}

У сучасних умовах серед важливих напрямів агропромислового комплексу України є стабілізація і нарощування виробництва зернової продукції та поліпшення ії якісних показників, яке забезпечить продовольчу безпеку держави та підвищить її роль на світовому ринку експортерів зерна. Важливе значення у розв'язанні цього завдання належить зростанню продуктивності посівів пшениці озимої як основної зернової культури країни $[1,2]$. 


\section{СІЛЬСЬКЕ ГОСПОДАРСТВО. РОСЛИННИЦТВО}

Оптимізація систем удобрення є не тільки важливим прийомом підвищення продуктивності польових культур, але й зниження собівартості врожаю, забезпечення його нормативної якості, зменшення залежності від несприятливих погодно-кліматичних чинників [3-5].

Дослідження ряду науковців свідчать про істотний вплив рівня забезпечення рослин культури елементами мінерального живлення впродовж періоду вегетації на підвищення врожайності та покращення якості зерна пшениці озимої в умовах зони Лісостепу [6-10].

Дослідження, проведені в південній частині України, свідчать, що внесення мінеральних добрив у дозі $\mathrm{N}_{30} \mathrm{P}_{30}$ під передпосівну культивацію та обприскування посівів на час відновлення весняної вегетації та у фазу виходу рослин у трубку препаратами Ескорт-біо та Органік Д2 забезпечує найбільш оптимальні умови для росту і розвитку рослин та формування елементів структури врожаю та продуктивності пшениці озимої $[11,12]$.

У Південному Степу України спостерігали, що азотні добрива, внесені прикореневим способом у фазу початок виходу у трубку, максимально підвищували урожайність пшениці озимої як порівняно 3 контролем, так і відносно до фонового внесення фосфорно-калійних добрив. Також відзначено збільшення вмісту білка і скловидності зерна [13].

Дослідження, одержані на дослідному полі Миколаївського НАУ впродовж 2011-2016 рр., дали змогу виявити високу ефективність як мінеральних добрив, так і застосування Біодеструктора стерні за умови вирощування пшениці озимої після ячменю ярого та гороху [14].

У північній частині Степу України на Синельниківській селекційно-дослідній станції Інституту зернового господарства встановлено, що найбільш ефективною нормою мінеральних добрив під пшеницю озиму за розміщення іiї в сівозміні після гороху $є \mathrm{~N}_{90} \mathrm{P}_{60} \mathrm{~K}_{60}$ у передпосівну культивацію + $\mathrm{N}_{30}$ у позакореневе підживлення, а після соняшнику $-\mathrm{N}_{90} \mathrm{P}_{60} \mathrm{~K}_{60}$ у передпосівну культивацію $+\mathrm{N}_{30}$ рано навесні $+\mathrm{N}_{30}$ у фазі виходу у трубку [15].

Отже, проведений аналіз літературних джерел свідчить про актуальність проведення досліджень 3 вивчення ефективності добрив за умови вирощування пшениці озимої у зв'язку зі щорічним оновленням сортових ресурсів, погіршенням складу попередників та необхідністю збільшення виробництва продовольчого зерна, зважаючи на динамічні зміни клімату.

Мета досліджень - з'ясувати вплив різних доз мінеральних добрив на водоспоживання посівів пшениці озимої та іiї продуктивність.

Завдання дослідження: вивчити вплив різних доз мінеральних добрив на використання вологи посівами пшениці озимої; дослідити вплив мінеральних добрив на урожайність зерна пшениці озимої.

Матеріали і методи досліджень

Дослідження проводили протягом 2016-2019 рр., на базі Полтавської державної сільськогосподарської дослідної станції імені М. І. Вавилова Інституту свинарства і АПВ НААН.

Грунт дослідного поля - чорнозем типовий малогумусний важкосуглинковий, із вмістом гумусу в шарі 0-20 см 4,9-5,2 \%; азоту, що легко гідролізується - 5,4-6,8 мг/100 г грунту (за Тюріним та Кононовою); $\mathrm{P}_{2} \mathrm{O}_{5}$ в оцтовокислій витяжці - 10,0-12,3 мг/100 г грунту (за Чириковим); обмінного калію - 17,0-17,7 мг/100 г грунту (за Масловою), реакція грунтового розчину слабокисла (рН сольової витяжки $-6,3)$.

Повна схема досліду приведена в таблиці 1. Повторність досліду триразова. Розміщення варіантів і повторень - рендомізоване. Посівна площа ділянки дорівнювала $120 \mathrm{~m}^{2}$, облікова $-80 \mathrm{~m}^{2}$. Загалом технологія вирощування пшениці озимої була загальноприйнятою для зони Лівобережного Лісостепу України, окрім елементів, що вивчали. В досліді висівали сорт пшениці озимої Нива одеська, а попередником культури була соя.

Для розв'язання поставлених завдань був проведений комплекс спостережень, обліків і аналізів. Вологість грунту визначали ваговим методом на початку відновлення вегетації навесні і на час збирання. Сумарні витрати вологи та коефіцієнт водоспоживання культури визначали методом спрощеного водного балансу [16].

Облік урожайності проводили на кожній ділянці методом суцільного обмолоту комбайном SAMPO-500, з подальшим зважуванням, визначенням вологості зерна, чистоти. 


\section{СІЛЬСЬКЕ ГОСПОДАРСТВО. РОСЛИННИЦТВО}

Результати досліджень та їх обговорення

У результаті проведених досліджень встановлено, що різні дози застосування мінеральних добрив як фактор управління перебігом продукційних процесів у технології вирощування, позитивно впливали на елементи структури врожаю пшениці озимої (табл. 1).

1. Структурний аналіз снопових зразків пшениці озимої, середнє за 2016-2019 рр.

\begin{tabular}{|c|c|c|c|c|c|}
\hline Варіанти удобрення & $\begin{array}{c}\text { Кількість ро- } \\
\text { слин, шт./м² }\end{array}$ & $\begin{array}{c}\text { Коефіцієнт } \\
\text { кущіння }\end{array}$ & $\begin{array}{c}\text { Висота рос- } \\
\text { лин, см }\end{array}$ & $\begin{array}{c}\text { Довжина } \\
\text { колоса, см }\end{array}$ & $\begin{array}{c}\text { Кількість зе- } \\
\text { рнин у колосі, } \\
\text { шт. }\end{array}$ \\
\hline Без добрив & 289,4 & 1,44 & 66,3 & 6,9 & 33,7 \\
\hline $\mathrm{N}_{90} \mathrm{P}_{60} \mathrm{~K}_{60}$ & 292,1 & 1,78 & 71,7 & 7,2 & 35,3 \\
\hline $\mathrm{N}_{60} \mathrm{P}_{60} \mathrm{~K}_{60}+\mathrm{N}_{30}$ & 286,3 & 1,91 & 72,5 & 7,3 & 36,2 \\
\hline $\mathrm{N}_{45} \mathrm{P}_{30} \mathrm{~K}_{30}$ & 288,2 & 1,65 & 69,1 & 7,1 & 34,3 \\
\hline $\mathrm{N}_{110} \mathrm{P}_{90} \mathrm{~K}_{50}$ & 285,6 & 1,85 & 72,8 & 7,4 & 36,5 \\
\hline $\mathrm{N}_{80} \mathrm{P}_{90} \mathrm{~K}_{50}+\mathrm{N}_{30}$ & 287,1 & 1,94 & 73,3 & 7,5 & 37,1 \\
\hline $\mathrm{N}_{55} \mathrm{P}_{45} \mathrm{~K}_{25}$ & 283,5 & 1,72 & 70,6 & 7,3 & 35,0 \\
\hline
\end{tabular}

Внесення мінеральних добрив у нормі $\mathrm{N}_{90} \mathrm{P}_{60} \mathrm{~K}_{60}$ під основний обробіток грунту зумовило зростання коефіцієнта кущіння порівняно 3 контролем на 0,34 одиниці або на 23,6\%. У варіанті 3 аналогічною нормою мінеральних добрив за умови перенесення частини азоту, зокрема $\mathrm{N}_{30}$ iз основного внесення в ранньовесняне підживлення поверхневим способом, відзначено збільшення коефіцієнта кущіння на 32,6 \% відносно контролю і на 7,2 \% порівняно 3 попереднім варіантом удобрення. У разі зменшення вищенаведеної норми добрив на 50 \% спостерігали зниження кількості продуктивних стебел у посіві пшениці озимої на 44,5 шт./ ${ }^{2}$ або 8,6\%. Внесення мінеральних добрив у нормі $\mathrm{N}_{110} \mathrm{P}_{90} \mathrm{~K}_{50}$, розрахованої на винос запланованим врожаєм $(5,0 \mathrm{~T} / \mathrm{ra})$, сприяло інтенсифікації ростових процесів, і відповідно, формуванню більшої кількості продуктивних пагонів. За умови такого варіанта удобрення відзначено збільшення коефіцієнта кущіння рослин пшениці озимої на 28,5 \% порівняно 3 контролем і на $3,9 \%$ відносно загальноприйнятої для регіону норми $\left(\mathrm{N}_{90} \mathrm{P}_{60} \mathrm{~K}_{60}\right)$. Диференційоване застосування азоту, а саме використання частини норми для ранньовесняного підживлення по мерзлоталому грунту виявилося більш ефективним за впливом на процес кущіння рослин, ніж внесення всієї дози під основний обробіток грунту. За таких умов відбулося підвищення коефіцієнта кущіння на 4,7 \%. Внесення половинної норми мінеральних добрив призвело до зменшення числа продуктивних стебел на $11,3 \%$.

Мінеральні добрива як чинник інтенсифікації ростових процесів сприяли підвищенню показника лінійного росту рослин пшениці озимої. Результати досліджень свідчать, що за умови внесення різних норм мінеральних добрив і диференційованого використання азоту висота рослин пшениці збільшилася на 2,8-7,0 см або 4,2-10,6 \% порівняно з варіантом без добрив. Максимальне значення цього показника одержано за умови внесення $\mathrm{N}_{80} \mathrm{P}_{90} \mathrm{~K}_{50}+\mathrm{N}_{30}$. У досліді також спостерігається тенденція до збільшення висоти рослин культури у разі перенесення частини азоту в підживлення по мерзлоталому грунту.

Використання мінеральних добрив у технології вирощування пшениці озимої також позитивно позначилося і на довжині колоса. В досліді у варіантах із внесенням мінеральних добрив спостерігали збільшення довжини колоса на 0,2-0,6 см або 2,9-8,7 \%, порівняно з контролем. Варто зазначити, що між мінімальною і максимальною нормами використання добрив різниця за цим показником становить 0,4 см або 5,6\%.

Результати досліджень свідчать, що внесення різних норм мінеральних добрив позитивно впливало на озерненість колоса пшениці озимої. Так, залежно від норми застосування добрив кількість зернин у колосі збільшилася щодо контролю на 0,6-3,4 шт., або 1,8-10,1 \%. У досліді відзначено, що за умови внесення половинних норм мінеральних добрив формувалася закономірно менша кількість зернин у колосі порівняно з повною нормою, але водночас цей показник перевищував контроль на $1,8-3,9 \%$.

У зоні Лівобережного Лісостепу України серед найбільш важливих чинників досягнення високих та сталих урожаїв сільськогосподарських культур, зокрема і пшениці озимої, $є$ нагромадження і ефективне використання вологи. Негативний вплив дефіциту доступної вологи у грунті не обмежується 


\section{СІЛЬСЬКЕ ГОСПОДАРСТВО. РОСЛИННИЦТВО}

лише гальмуванням росту і розвитку культури, але й значно знижує ефективність агротехнічних прийомів інтенсифікації технології вирощування [17].

Проведені дослідження доводять, що використання мінеральних добрив у технології вирощування пшениці озимої забезпечує більш ефективне використання доступної вологи грунту на формування одиниці врожаю культури (табл. 2). У разі внесення різних норм мінеральних добрив сумарне водоспоживання становило 539-579 м³/т, що на 46-86 м³/т або 7,4-13,8 \% менше, ніж у варіанті без використання добрив. Потрібно зазначити, що найменші сумарні витрати вологи з грунту $539 \mathrm{~m}^{3} /$ б були за умови внесення до основного удобрення $\mathrm{N}_{80} \mathrm{P}_{90} \mathrm{~K}_{50}$ плюс $\mathrm{N}_{30}$ у ранньовесняне підживлення по мерзлоталому грунту. Результати досліджень також свідчать про більш раціональне використання вологи на формування одиниці врожаю основної продукції у разі перенесення частини азоту з основного внесення у підживлення рано навесні.

2. Водоспоживання та урожайність пшениці озимої залежно від норми та способів внесення мінеральних добрив, середнє за 2016-2019 рр.

\begin{tabular}{|c|c|c|c|c|c|}
\hline \multirow{2}{*}{ Варіанти удобрення } & \multicolumn{2}{|c|}{$\begin{array}{c}\text { Запаси продуктивної } \\
\text { вологи в метровому шарі } \\
\text { грунту, мм }\end{array}$} & \multirow{2}{*}{$\begin{array}{c}\text { Загальні ви- } \\
\text { трати вологи } \\
\text { за вегетацій- } \\
\text { ний період, } \\
\text { мм }\end{array}$} & \multirow{2}{*}{$\begin{array}{l}\text { Сумарне водос- } \\
\text { поживання, } \text { м }^{3} / \text { }\end{array}$} & \multirow{2}{*}{$\begin{array}{c}\text { Урожайність, } \\
\text { т/га }\end{array}$} \\
\hline & $\begin{array}{c}\text { на час відно- } \\
\text { влення веге- } \\
\text { тації }\end{array}$ & $\begin{array}{c}\text { на час } \\
\text { збирання }\end{array}$ & & & \\
\hline Без добрив & 134,2 & 68,5 & 324,7 & 625 & 5,19 \\
\hline $\mathrm{N}_{90} \mathrm{P}_{60} \mathrm{~K}_{60}$ & 135,3 & 66,3 & 328,0 & 569 & 5,76 \\
\hline $\mathrm{N}_{60} \mathrm{P}_{60} \mathrm{~K}_{60}+\mathrm{N}_{30}$ & 134,7 & 65,4 & 328,3 & 559 & 5,87 \\
\hline $\mathrm{N}_{45} \mathrm{P}_{30} \mathrm{~K}_{30}$ & 134,6 & 66,8 & 326,8 & 579 & 5,64 \\
\hline $\mathrm{N}_{110} \mathrm{P}_{90} \mathrm{~K}_{50}$ & 135,4 & 65,5 & 328,9 & 551 & 5,97 \\
\hline $\mathrm{N}_{80} \mathrm{P}_{90} \mathrm{~K}_{50}+\mathrm{N}_{30}$ & 135,5 & 65,2 & 329,3 & 539 & 6,11 \\
\hline $\mathrm{N}_{55} \mathrm{P}_{45} \mathrm{~K}_{25}$ & 134,6 & 66,3 & 327,3 & 566 & 5,78 \\
\hline HIP 0,95 & 5,4 & 3,8 & - & - & 0,38 \\
\hline
\end{tabular}

Узагальнюючим показником ефективності того чи того агротехнічного заходу в технології вирощування сільськогосподарських культур є досягнутий рівень продуктивності. Результати досліджень свідчать, що внесення мінеральних добрив забезпечує істотне підвищення урожайності зерна пшениці озимої порівняно з варіантом без добрив (табл. 2). Приріст урожайності на експериментальних варіантах відносно контролю становив 0,45-0,92 т/га або 8,8-17,7\%. Максимальну реалізацію біологічного потенціалу продуктивності культури відзначено у разі внесення найбільшої кількості мінеральних добрив, зокрема $\mathrm{N}_{80} \mathrm{P}_{90} \mathrm{~K}_{50}+\mathrm{N}_{30}$. Результати польового експерименту також вказують на стійку тенденцію щодо підвищення урожайності зерна пшениці озимої за умови поєднання двох способів внесення мінерального азоту добрив - під основний обробіток грунту та ранньовесняне підживлення.

Отже, на підставі одержаних результатів досліджень встановлено важливу роль використання мінеральних добрив у регулюванні водоспоживання посівами пшениці озимої та управлінні формуванням структурних елементів і загалом продуктивності культури.

Результати досліджень, одержані в різних грунтово-кліматичних умовах, також свідчать про позитивне значення мінеральних добрив у зменшенні випаровування рослинами вологи і втрати ії з грунту. За даними досліджень, на формування 1 тонни зерна озимої пшениці у варіанті без добрив витрачалося 122,8 т води, а при їх внесенні - лише 60,4 т, тобто вдвічі менше $[18,19]$.

Підвищення урожайності пшениці озимої в результаті застосування добрив відзначено за результатами досліджень в умовах Правобережного Лісостепу, яке за умови мінеральної системи удобрення становило 31-71 \%, органічної - 26-60 \%, органо-мінеральної - 35-73 \% [20]. Результати досліджень ДУ Інституту сільського господарства степової зони свідчать, що найвищу врожайність (5,25 т/га) від використання азотних добрив забезпечило внесення з осені $\mathrm{N}_{60}$ (КАC) $\mathrm{P}_{60} \mathrm{~K}_{60} 3$ подальшим позакореневим підживлення КАС у фазі кущіння навесні [21].

\section{Висновок}

Отже, дослідження підтверджують тенденцію до більш економного витрачання доступної вологи 
грунту на утворення врожаю основної і побічної продукції пшениці озимої за умови використання добрив. Формування найвищої врожайності зерна 6,11 т/га забезпечило внесення $\mathrm{N}_{80} \mathrm{P}_{90} \mathrm{~K}_{50}$ під основний обробіток грунту плюс підживлення $\mathrm{N}_{30}$ по мерзлоталому грунту поверхневим способом.

Перспективи подальшої роботи в иьому напрямі. Перспектива подальших досліджень полягає в інтенсифікації технології вирощування пшениці озимої шляхом застосування мікродобрив, мікробіологічних препаратів, стимуляторів росту рослин нового покоління, що дасть змогу суттєво підвищити зернову продуктивність культури та збільшити валове виробництво зерна в умовах Лівобережного Лісостепу України.

\section{References}

1. Oliinyk, K. M., Blazhevych, L. Iu., \& Buslaieva N. H. (2018).Vplyv tekhnolohii vyroshchuvannia na urozhainist pshenytsi ozymoi v pivnichnomu Lisostepu. Zbirnyk Naukovykh Prats NNTs «Instytut Zemlerobstva NAAN», 1, 15-22 [In Ukrainian].

2. Marenych, M. M. (2019).Efektyvnist sposobiv zastosuvannia huminovykh stymuliatoriv v tekhnolohii vyroshchuvannia pshenytsi ozymoi. Visnyk Poltavskoi Derzhavnoi Ahrarnoi Akademii, 3, 26-34. doi: 10.31210/visnyk2019.03.03 [In Ukrainian].

3. Nosko, B. S., Medvediev, V. V., Nepochatov, O. P., \& Skorokhod, V. \I. (2000). Rol dobryv u pidvyshchenni efektyvnosti zemlerobstva v posushlyvykh umovakh. Visnyk Ahrarnoi Nauky, 5, 11-15 [In Ukrainian].

4. Shakalyi, S. N. (2015). Vlyianye myneralnoho udobrenyia na kachestvo zerna pshenytsы miahkoi ozymoi. Vestnyk Kurhanskoi Hosudarstvennoi Selskokhoziaistvennoi Akademyy, 1, 40-43 [In Russian].

5. Hanhur, V. V., Pavliuk, O. O., \& Marenych, M. M. (2008). Efektyvnist faktoriv intensyfikatsii v tekhnolohii vyroshchuvannia ozymoi pshenytsi. Visnyk Poltavskoi Derzhavnoi Ahrarnoi Akademii, 2, 43-46 [In Ukrainian].

6. Lisovyi, M. V., Shymel, V. V., \& Nikonenko, V. M. (2019). Efektyvnist mineralnykh dobryv pid pshenytsiu ozymu na chornozemi typovomu Lisostepu livoberezhnoho vysokoho. Visnyk Ahrarnoi Nauky, 5 (794), 16-21. doi: 10.31073/agrovisnyk201905-01 [In Ukrainian].

7. Kononiuk, L. M., \& Dmytrenko, O. V. (2007). Vplyv tekhnolohii vyroshchuvannia na vrozhainist ta yakist zerna pshenytsi ozymoi v Pivnichnomu Lisostepu. Zbirnyk naukovykh Prats Natsionalnoho Naukovoho Tsentru «Instytut Zemlerobstva UAAN», 2, 52-57 [In Ukrainian].

8. Onychko, T. O., \& Trotsenko, V. I. (2013). Efektyvnist tekhnolohii vyroshchuvannia pshenytsi ozymoi v umovakh Pivnichno-Skhidnoho Lisostepu Ukrainy. Visnyk Sumskoho Natsionalnoho Ahrarnoho Universytetu, 3, 179-181 [In Ukrainian].

9. Pikovska, O. V., \& Vitvitska, O. I. (2016). Vplyv zastosuvannia solomy na pokaznyky rodiuchosti chornozemu typovoho. Naukovyi Visnyk Natsionalnoho Universytetu Bioresursiv i Pryrodokorystuvannia Ukrainy, 235, 160-166 [In Ukrainian].

10. Oliinyk, K. M., Blazhevych, L. Iu., \& Buslaieva, N. H. (2018). Vplyv tekhnolohii vyroshchuvannia na urozhainist pshenytsi ozymoi $\mathrm{v}$ pivnichnomu Lisostepu. Zbirnyk naukovykh prats NNTs «Instytut zemlerobstva NAAN», 1, 15-22 [In Ukrainian].

11. Hamaiunova, V. V., Panfilova, A. V., \& Averchev, O. V. (2018). Produktyvnist pshenytsi ozymoi zalezhno vid elementiv tekhnolohii vyroshchuvannia v umovakh Pivdennoho Stepu Ukrainy. Tavriiskyi Naukovyi Visnyk, 103, 16-22 [In Ukrainian].

12. Panfilova, A. V., \& Hamaiunova, V. V. (2018). Formuvannia nadzemnoi masy sortiv pshenytsi ozymoi zalezhno vid optymizatsii zhyvlennia v umovakh Pivdennoho Stepu Ukrainy. Visnyk Lvivskoho Natsionalnoho Ahrarnoho Universytetu, 22 (1), 332-339 [In Ukrainian].

13. Kryvenko, A. I. (2018). Optymizatsiia norm i terminiv pidzhyvlennia pshenytsi ozymoi azotnymy dobryvamy u Pivnichnomu Stepu Ukrainy. Visnyk ahrarnoi nauky Prychornomoria, 4, 55-61. doi: 0.31521/2313-092X/2018-4(100)-8 [In Ukrainian].

14. Panfilova, A. V., Hamaiunova, V. V., Drobitko A. V. (2019). Urozhainist pshenytsi ozymoi zalezhno vid poperednyka ta biodestruktora sterni. Visnyk Poltavskoi Derzhavnoi Ahrarnoi Akademii, 3, 18-25. doi: 10.31210/visnyk2019.03.02 [In Ukrainian].

15. Sereda, I. I. (2009). Vplyv poperednykiv i mineralnykh dobryv na vmist volohy $\mathrm{v}$ hrunti ta produktyvnist ozymoi pshenytsi. Biuleten Instytutu Zernovoho Hospodarstva UAAN, 36, 32-35 [In Ukrainian]. 
16. Yeshchenko, V O., Kopytko, P. H., Kostohryz, P. V, \& Opryshko, V. P. (2014). Osnovy naukovykh doslidzhen v ahronomii: Pidruchnyk. Vinnytsia: PP «TD «Edelveis i K»» [In Ukrainian].

17. Litvinov, D. V. (2007). Dynamika produktyvnoi volohy v grunti za vyroshchuvannia zernovykh kolosovykh kultur. Zbirnyk Naukovykh Prats Nnts «Instytut Zemlerobstva UAAN», 3-4, 34-38 [In Ukrainian].

18. Blyaherova, P. M., Zabaznyj, P. A., \& Pruckova, M. G. (1973). Pshenica. 2-e yzdanye, pererabotannoe y dopolnennoe. Moskva: Kolos [In Russian].

19. Kaminskyi, V.F., \& Hanhur, V. V. (2018). Dynamika produktyvnoi volohy v hrunti za vyroshchuvannia pshenytsi ozymoi v sivozminakh livoberezhnoho Lisostepu Ukrainy. Visnyk Poltavskoi Derzhavnoi Ahrarnoi Akademii, 3, 11-14. doi: 10.31210/visnyk2018.03.01 [In Ukrainian].

20. Hospodarenko, H. M., \& Cherno, O. D. (2016). Yakist zerna pshenytsi ozymoi za tryvaloho zastosuvannia dobryv u polovii sivozmini. Visnyk Umanskoho Natsionalnoho Universytetu Sadivnytstva, 1, 11-15 [In Ukrainian].

21. Zheliazkov, O. I. (2015). Efektyvnist zastosuvannia azotnykh dobryv pry vyroshchuvanni pshenytsi ozymoi v umovakh Pivnichnoho Stepu. Visnyk Zhytomyrskoho Natsionalnoho Ahroekolohichnoho Universytetu, 1 (47), 1, 156-162 [In Ukrainian].

Стаття надійшла до редакції 20.07.2020 р.

Бібліографічний опис для цитування:

Гангур В. В., Кочерга А. А., Пипко О. С., Кабак Ю. І., Лень О. І. Вплив мінеральних добрив на водоспоживання та продуктивність пшениці озимої. Вісник ПДАА. 2020. № 3. С. 54-60.

(c) Гангур Володимир Васильович, Кочерга Анатолій Андрійович, Пипко Олександр Сергійович, Кабак Юрій Іванович, Лень Олександр Іванович, 2020 